Article

\title{
Determinants of Farm Resilience to Climate Change: The Role of Farmer Entrepreneurship and Value Chain Collaborations
}

\author{
Daniel Kangogo, Domenico Dentoni * and Jos Bijman (1) \\ Business Management \& Organisation Group, Wageningen University \& Research, Hollandseweg 1, \\ 6706 KN Wageningen, The Netherlands; daniel.kangogo@wur.nl (D.K.); jos.bijman@wur.nl (J.B.) \\ * Correspondence: domenico.dentoni@wur.nl
}

Received: 27 December 2019; Accepted: 20 January 2020; Published: 23 January 2020

check for updates

\begin{abstract}
The concept of resilience gained traction in academic, policy, and development discourse in recent years, yet its conceptualization and application at the farm level has received little attention. For instance, recent policy recommendations present farm resilience as a silver bullet in dealing with agricultural risks and uncertainty, and in achieving sustainable agri-food systems. Yet, the question of what determines farm resilience in a smallholder farming set-up remains fuzzy. To address this knowledge gap, we firstly develop a novel conceptual framework based on determinants of farm resilience and farmer adaptive capacity as a pathway through which farm resilience is strengthened. The emphasis on adaptive capacity responds to a conceptual weakness inherent in studies that present socio-ecological systems as static systems. Secondly, based on a literature review, we propose mechanisms through which farmer entrepreneurship, membership in farmer organization, and farmer-buyer relationships may influence farmer adaptive capacity and thereby farm resilience. Based on our conceptual understanding of the determinants of farm resilience, we recommend approaches that augment farmer entrepreneurship, support farmer organizations, and strengthen farmer-buyer relationships.
\end{abstract}

Keywords: resilience; adaptive capacity; entrepreneurship; farmer organizations; farmer-buyer relationships

\section{Introduction}

Because of the globally alarming news on climate change and its impact on agriculture, transitions toward more ecologically sustainable agri-food systems call for a deep re-thinking of farming practices [1]. Yet, despite the environmental alarms, both farmers and their value chain partners experience major difficulties in making changes toward more sustainable practices. This calls for a deeper understanding of farmers' motivations and barriers to the development of environmentally sustainable practices [2]. With respect to the farmers' motivations, a rich body of literature focused on the adoption of sustainable agricultural practices [3,4]. However, a knowledge gap persists in understanding how farmers continuously adapt their farming practices to unpredictably changing environmental conditions. Attempts to fill this knowledge gap are important in order to come up with policies that support farms facing unpredictable climatic conditions.

This paper conceptualizes the determinants of farm resilience to shed light on when, why, and how farmers continuously adapt their farming practices in response to climate change shocks. According to Campbell et al. [5] (2014), building farm resilience is a prerequisite for farms that are operating in increasingly consistent and unpredictable climate shocks. In general, resilience refers to "the ability of a system to absorb disturbance and reorganize while undergoing change so as to still retain essentially the 
same function, structure, identity, and feedbacks" [6]. Following this, resilience is viewed as an essential building block for sustainability in the face of growing complexity and uncertainty [7]. At the farm level, resilience refers to the ability of farms to adapt to climatic, social, and market shocks [8]. This ability of farms to adapt can be improved through internal and external interventions [9], and tapping into farmer characteristics which facilitate self-organization and innovative problem-solving [10].

In general, Gitz and Meybeck (2012) [11] identified three strategies for building resilience. These strategies are reducing exposure, reducing sensitivity, and increasing adaptive capacity.

(a) Reducing exposure implies reducing the likelihood of a particular risk occurring, as well as the severity. This strategy makes a distinction between climatic and non-climatic shocks. For some non-climatic shocks, it may be possible to reduce the likelihood of their occurrence and severity at the farm level, while this is difficult for climatic shocks.

(b) Reducing sensitivity of the farm to shocks implies identification of the likely risk and developing response mechanisms to reduce the impacts. For instance, sensitivity to drought can be reduced by developing and using drought-tolerant varieties. This strategy requires that the likely risks are measurable and identifiable in advance; however, this is not always possible at farm level.

(c) Increasing adaptive capacity implies enhancing the capacity of farmers to respond promptly and effectively to the effects of climate change, for instance, through the use of novel management practices and innovative technologies [12,13]. Farmer adaptive capacity is associated with increasing the options to manage climate change and with improving decision-making under uncertainty [14].

We focus on farmer adaptive capacity defined as the human potential to convert and reconvert existing resources into effective adaptation strategies [15]. In other words, adaptations strategies taken by farmers in response to climate change are a manifestation of their adaptive capacity [16]. In the context of farming, farmer adaptive capacity is, therefore, a prerequisite for building farm resilience to climate change [17]. Farmer adaptive capacity is a function of the ability to access, organize, or reorganize resources, and of linkages to organizations that influence the access to the necessary resources $[18,19]$.

While farmer adaptive capacity as a means of building and/or strengthening farm resilience is important, it so far received little attention in climate change adaptation research. We contribute in two ways to this research gap and to the ongoing conceptual development of farm resilience. Firstly, focusing on farmer adaptive capacity rather than on farm performance measures represents a new sustainable paradigm as it shifts the analysis from static outcome indictors such as income and yields to process indicators such as farmer adaptive capacity. In this way, farmer adaptive capacity at the farm level is viewed as a characteristic of the farmer and the relationships that farmers develop to prepare and respond to the impacts of climate change [20]. Secondly, to explain how farmer adaptive capacity can be influenced, we build upon the so-far disconnected literature on farm resilience [21,22], supply chain resilience [23,24], entrepreneurship [25-27], and farmer organizations [28-30].

We emphasize the role of the farmers since climate change adaptation behavior was shown to be the result of the cognitive process of the farmer [31,32], which also includes entrepreneurship [33]. Therefore, to understand farmer adaptive capacity as the potential to convert and reconvert existing resources into effective adaptation strategies, there is a need to incorporate the farmer psychological factors, particularly entrepreneurship, in the assessment. In addition, value chain collaboration, both horizontal with other farmers (through farmer organizations) and vertical with the buyers of produce (through farmer-buyer relationships), also contributes to improving farmer adaptive capacity. We conjecture that (a) farmer entrepreneurship, (b) membership in farmer organizations (FOs), and (c) the nature of farmer-buyer relationships play powerful roles in shaping farm resilience through their influence on the farmer adaptive capacity.

Considering farmer entrepreneurship, membership in farmer organizations (FOs) and the nature of farmer-buyer relationships as determinants of farmer adaptive capacity respond to the call to 
identify approaches that enhance the ability of farms to adapt to climate change. Firstly, farmer entrepreneurship entails how farmers proactively adapt, take calculated risks, and innovate in response to stimuli from both internal and external environments [26,34]. Secondly, the FOs represent the role of collective action in supporting farmer adaptive capacity [35]. Thirdly, the nature of farmer-buyer relationships represents the potential mechanism through which the nature of market systems build farmers' ability to adapt to climate change [36]. Regardless of the type of collaboration that famers are embedded in, Pelling et al. (2008) [37] argued that organizational structures are central for adaptive capacity. These organizational structures provide space for farmers to interact, communicate, experiment, and learn from each other in attempts to respond to changes facing their farms [38].

Our conceptual framework extends the work of Vroegindewey and Hodbod (2018) [39] on agricultural value chain resilience. It does this by conceptualizing farm resilience and identifying farmer adaptive capacity as a key pathway to farm resilience.

\section{An Illustration of the Determinants of Farm Resilience: Potato Farming in Kenya}

To support our conceptual work, we refer to an illustrative example from potato farming in Kenya. Potato is the second most important crop in Kenya after maize. Potato is grown as both a food and a cash crop by smallholder farmers who produce mainly under rain-fed farming conditions. Like with other crops, potato growing is already crippling with the effect of climate change, including unpredicted rainfall and frequent droughts. This forces potato farmers to adapt in different ways including the adoption of climate-smart agriculture practices such as intercropping, which conserves moisture, increases soil fertility, spreads the risk of crop failure, and reduces cost of renting land, as different crops can be grown in the same plot; changing potato planting dates and investing in irrigation among other options. The Kenya climate-smart agriculture implementation framework 2018-2027 [40] contains a comprehensive list of climate-smart agriculture practices currently being promoted in Kenya. While adoption levels of these practices continue to grow, the levels still fall below $50 \%$ for most of the practices [41,42]. Our household survey among a sample of Kenyan potato farmers indicated that irrigation, soil testing for crop and fertilizer recommendation, changing of planting dates, and soil and water conservation measures were adopted by about $31 \%, 21 \%, 49 \%$, and $36 \%$ of the farmers, respectively.

Interestingly, we observed that inhabitants of urban areas are renting land to grow potatoes in rural areas, particularly where they can invest in irrigation. These new entrants in potato farming produce potatoes mainly under irrigation and in the varieties that are demanded in urban markets.

There is an emerging development in the farmer groups, where potato farmers are strengthening their farmer organizations through formalizing them into stronger units such as cooperatives. These stronger and more formal units not only allow member farmers to take advantage of collective activities in times of adverse climatic events, but they also allow them to tap into resources and services from non-governmental organizations, county governments, and other stakeholders. In Meru county, for instance, several small potato farmer groups merged to form a potato cooperative. The cooperative now provides farmer members with opportunities to access credit and good-quality seed (certified seed and in the variety that is demanded in the market), buy crop insurance policy, and access training through cooperative field extension officers and opportunities to participate in contract farming arrangements. In some cases, the contractor provides its farmers with advisory services and inputs, especially certified seeds in the varieties that they require. This takes the burden away from the farmers and encourages further investment in potato production despite the effects of climate change. Contract farming models underscore the role played by farmer-buyer relationships in influencing farmer adaptive capacity.

From this illustrative example and focusing on the farmer as the key farm decision-maker, we can deduce three determinants of farm resilience. Firstly, farmers need to make deliberate investments in climate adaptation strategies, such as the adoption of climate-smart agriculture (CSA) practices. However, the adoption of the CSA practices not only depends on the farmer and farm characteristics, 
but also on underlying psychological factors $[43,44]$. Such psychological factors include farmer entrepreneurship [45]. Using our illustrative example, for inhabitants of urban areas to venture into potato farming in rural areas given their limited farming experience represents their entrepreneurship mindset, specifically their innovativeness, proactiveness, and risk-taking behavior. The same argument applies for the existing farmers who experiment with CSA practices such as intercropping, irrigation, and changing potato planting dates, given that these are not common practices in their current context. Bernier et al. (2015) [42], studying gender and institutional aspects CSA practices in Kenya, identified farmer innovativeness, education level, access to credit, and membership in community organization, among others, as significant determinants of the adoption of CSA in Kenya. Table 1 shows the differences between adopters and non-adopters of irrigation in terms of the variables age, gender, years of education, farm size, membership in farmer organization, and contract farming using empirical data from potato farmers in Kenya.

Table 1. Definition and descriptive statics for the variables.

\begin{tabular}{cccc}
\hline \multicolumn{2}{c}{ Variable } & Irrigation Adopters & Non-Adopters \\
\hline \multirow{2}{c}{ Age (years) } & & 50.4 & 49.2 \\
\hline \multirow{2}{*}{ Gender } & Male & $65.7 \%$ & $47.2 \%$ \\
& Female & $34.3 \%$ & $52.8 \%$ \\
\hline \multicolumn{2}{c}{ Education (years of schooling) } & 9 & 9 \\
\multicolumn{2}{c}{ Farm size (acres) } & 2.9 & 3.0 \\
\hline \multirow{2}{*}{ Membership in FO } & Nember & $70.2 \%$ & $60 \%$ \\
& Non-member & $29.8 \%$ & $40 \%$ \\
\hline \multirow{2}{*}{ Contract farming } & Contract & $40.4 \%$ & $15.2 \%$ \\
& Non-contract & $59.6 \%$ & $84.8 \%$ \\
\hline
\end{tabular}

Source: Authors based on household survey among potato farmers in Kenya, 2019.

The table shows that the adopters and non-adopters of irrigation differ in (a) gender, with male farmers adopting more than female farmers, and (b) membership in farmer organization, with members adopting more than non-members. We did not find a difference between adopters and non-adopters in terms of age, education, and farm size.

Secondly, farmers need support from various stakeholders to learn about and invest in adaptation strategies. This calls for farmers to engage in collaboration both horizontal with other farmers and vertical with the buyers of their produce. With respect to horizontal collaborations, we relate this to membership in FOs. Through membership, farmers benefit from access to services and resources necessary to adapt to the changing climate. For instance, farmers need credit to be able to invest in drought-tolerant seed varieties, to receive training on how to implement CSA practices, and to access stable and lucrative markets. Individually, smallholder farmers may not have the ability to access these resources; however, collectively with other farmers, they benefit from pooling of resources, accessing information, and learning from the experiences of others. This is reflected in our potato farming illustration where farmers join FOs or set up cooperatives that allow them to access resources and services.

Thirdly, the relationships that farmers build with their buyers may lead to a change in the farmer's production, investment, and marketing decisions. More precisely, a trading relationship characterized by collaborative engagement between farmers and buyers may trigger farmers to engage in adaptation strategies, such as investing in new productive assets, adopting CSA practices, and switching crops. Strong farmer-buyer relationships create space for cooperation, information sharing, and mutual learning, providing a competitive advantage for both the farmer and the buyer involved. Bijman (2008) [46] showed that, when they engage in a contract farming arrangement, farmers benefit from certainty to sell their products, higher income, and improved access to inputs, credit, and technical assistance. These are necessary for improving farmer adaptive capacity. In our 
illustration, farmers that have strong relationships with buyers benefit from assured markets, access to certified seeds in the varieties that are demanded in the market, and technical assistance.

Hence, as our illustrative example shows, it is worth zooming into farmer adaptive capacity as a plausible driver of farm resilience. In turn, it is possible to hypothesize that entrepreneurship, membership in FOs, and farmer-buyer relationships may shape farmer adaptive capacity. In the four sections below, we review each of these core concepts.

\section{Farmer Adaptive Capacity}

Farmer adaptive capacity to respond to climate change is critical for reducing farm vulnerability and building farm resilience [13]. It represents the pre-conditions that reflect the learning, and the flexibility to experiment and adopt innovations in response to a broad range of challenges [47]. Walker et al. (2002) [48] defined adaptive capacity as an attribute of management that creates opportunities for learning and provides the ability to experiment, adapt, and foster novel solutions in complex social-ecological environments. More precisely, Walker et al. (2004) [48] present adaptive capacity as the ability of actors in a system to influence resilience. This follows that the higher the adaptive capacity within a system, the higher the probability that the system will be resilient to climate change [49]. Accordingly, Cinner et al. (2018) [50] identified five domains that are necessary in building adaptive capacity for resilience. These are the assets that people can draw upon in times of need, the flexibility to change strategies, the ability to organize and act collectively, learning to recognize and respond to change, and the agency to determine when and how to change. Additionally, past research showed that an actor's adaptive capacity is shaped by interacting processes that occur at multiple scales, including membership in FOs and farmer-buyer relationships [35].

To stimulate adaptive capacity, Armitage (2007) [51] suggested that the following areas need to be understood: (a) the cross-scale relationships and networks among actors in a system, (b) the existing and evolving power relationships among actors, (c) the intangible resources such as trust that influence and shape collaboration and learning, and (d) the extent to which cultural norms and values are consistent with collective action and collaborative learning. This implies that improving adaptive capacity requires an understanding of the social, organizational, and institutional context [52]. Moreover, efforts to build adaptive capacity need to occur at multiple levels [53], since the effectiveness of these efforts is affected by the interactions among various levels.

At the farm level, the farmer's ability to diversify the farm, adopt drought-tolerant crop varieties, and implement irrigation has the potential to improve farm resilience. However, this farmer adaptive capacity is partly dependent on a conducive institutional environment, for instance, with extension services and access to finance [16,54]. Faced with weak farm support, farmers will largely depend on their individual ability to test and experiment, to recognize and respond to opportunities, and to manage risk [55].

Also the type of relationships that farmers have with their suppliers of inputs and buyers of outputs affects the farmer adaptive capacity. Milestad et al. (2010) [55], in studying the influence of markets on farmer adaptive capacity in Sweden, found that interaction between farmers and buyers creates mutual understanding. They argue that, with mutual understanding between farmers and buyers, farmers develop confidence and are more willing to invest in various adaptation strategies.

The potato farming example from Kenya illustrates how farmer adaptive capacity may drive investment decisions for farm resilience. In Meru county of Kenya, we observed farmers beginning to grow potato under irrigation given the prevalence of droughts in the recent past. Previously, irrigation was only applied to vegetables. However, not all farmers that have access to water irrigate their potato fields; others instead choose to reduce the area under potato. This observation suggests that not all farmers adapt or have the capacity to adapt to climate change. The example also leads us to question what drives some farmers to try new practices while others do not. 


\section{Farmer Entrepreneurship}

We put forward the argument that, in turbulent environments such as farming in the context of climate change, farmer entrepreneurship partly explains why some farmers better adapt to climate change than others. In particular, it is entrepreneurship orientation (EO) that differentiates between farmers that adapt and those that do not [56].

Taking the example of a potato farm, the farmer makes use of the human potential to decide on farm investment decisions to achieve desired goals. However, coupled with uncertainties, the farm investment decisions are constrained by the personality traits, preferences, and competences [57]. One of the often cited personality traits that distinguish farmers in decision-making is risk perception [58,59]. If we view a farmer as an entrepreneur, the logic also follows that proactiveness and innovativeness additionally influence farmers' decisions [25]. Therefore, we argue that a higher farmer EO leads to a higher level of farmer adaptive capacity.

As part of the EO construct, innovativeness is the ability to deviate from established practices and technologies toward supporting new ideas through learning and experimentation [34]. For farmers, this entails adoption of farm innovations such as the introduction of new management and cultivation practices [60]. Proactiveness is the ability to anticipate and act on future needs. It includes introducing product varieties in advance of others, thereby benefiting from a first-mover advantage [34], his presupposes that farmers with forward-looking characteristics capitalize on emerging opportunities that result from change. In addition to innovativeness and proactiveness, risk-taking behavior, as a third dimension of EO, implies the ability to invest resources in risky activities and processes.

From the illustrative example, the farmers that invest in the purchase of certified potato seed (often constituting a large portion of potato production costs) can be said to be risk-takers, particularly those who invest in potato varieties without assured market of the produce. In addition, farmers that apply irrigation on potato fields can be said to be engaging in process innovation and, thus, they can be viewed as innovative farmers relative to farmers that choose to keep the status quo of irrigating vegetables or those that reduce their potato area. Finally, farmers exhibit proactive characteristics when they are among the first to step into irrigating potato fields, especially where this is not common for the crop.

By incorporating farmer $\mathrm{EO}$ as a factor influencing farmer investment decisions on climate change adaptation strategies (see Figure 1), we extend the work of Grothmann and Patt (2005) [31] who proposed a socio-cognitive model of adaptation that compensates for the weaknesses of adaptation theories. While Grothmann and Patt (2005) [31] only focused on risk perception, in this paper, we add two other EO dimensions, proactiveness and innovativeness. This leads us to the following proposition:

$\mathbf{P}_{\mathbf{1}}$. Farmer EO positively influences farmer adaptive capacity and, thus, farm resilience.

The conceptual framework (Figure 1) proposes pathways through which farmer adaptive capacity enhances farm resilience. This framework provides the conceptual basis upon which future empirical studies may test the relationship among determinants of farm resilience. 


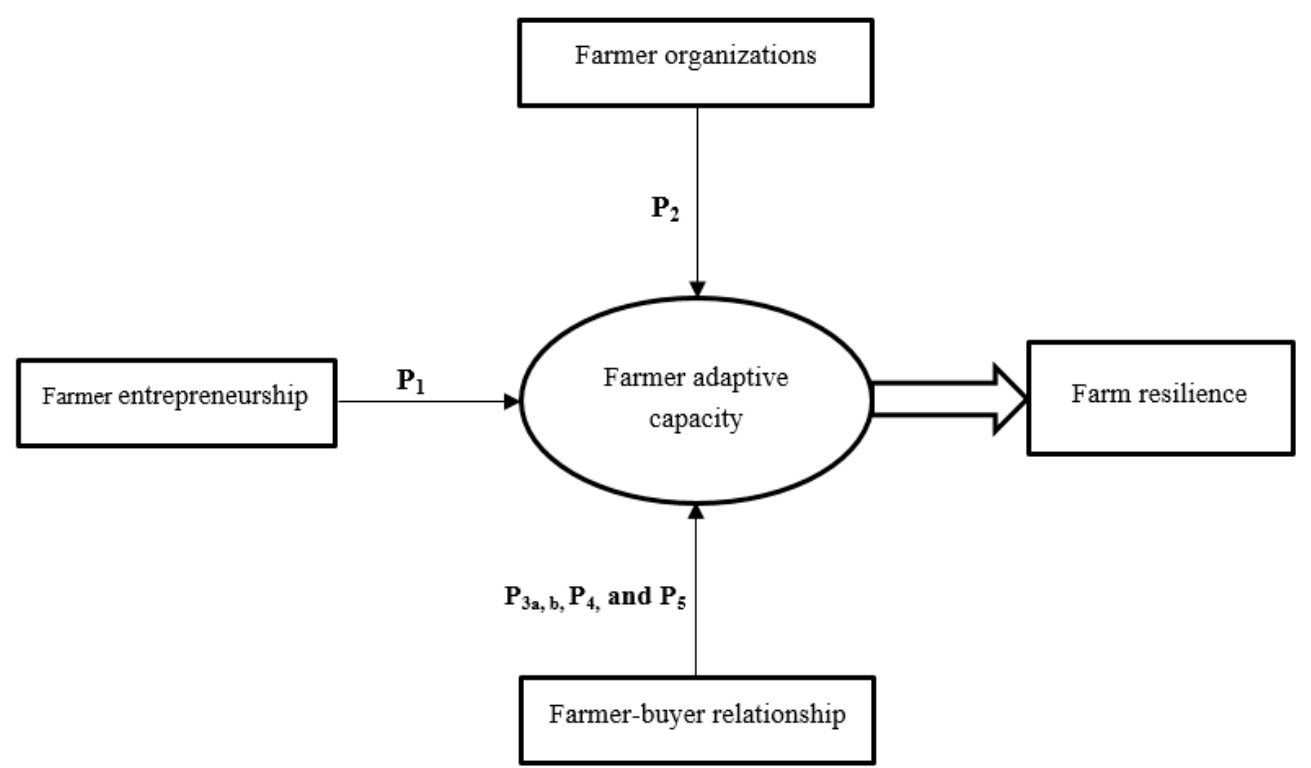

Figure 1. Author's conceptualization of the determinants of farm resilience.

\section{Farmer Organizations}

A farmer organization (FO) refers to a voluntary collective action organization owned and controlled by farmers to pursue common interests [61]. A FO can take different forms including cooperative, association, self-help group, and marketing group [62]. These are forms of self-organization that may provide resources and services that help farms to become resilient [10]. Currently, understanding of the nuanced role of FOs in supporting adaptation to climate change remains sketchy [63]. Yet, FOs are critical in providing the farmer with learning, legitimacy, governance, diffusion of innovation, and information necessary in adapting to changes.

FOs act as sources of information, learning platforms, and social support that farmers can rely on when dealing with climate change [64]. This implies that farmer adaptive capacity emerges from organizational contexts where farmers meaningfully interact, learn, and collaborate. FOs are flexible in responding to the complexity and dynamics of member needs, creating linkages with other actors, and providing space for knowledge generation and sharing [65].

A typical example of how the services provided by FOs may influence farmer adaptive capacity is through extension services, which provide farmers with learning opportunities that enhance their adaptive capacity for farm resilience [66]. In this way, FOs provide farmers with a space to experiment and innovate as a group or individually [67]. Particularly, experimentation enables farmers to adapt to the continuously changing environment [68] as it produces innovations and generates local knowledge that improves farmer adaptive capacity. Innovation relies on access to finance, information, and other resources, which can be accessed through participation in supportive institutions such as FOs, especially for resource-constrained smallholder farmers. In addition, FOs through their extension services, facilitate exchange programs for learning between experienced and less experienced farmers.

At farm level, the outcomes of extension services are changes in farming practices, for instance, crop rotation and the introduction of new crop varieties. FOs facilitate farmers to adopt new farming practices by providing access to technologies, finance, and technical backstopping during the adoption process $[69,70]$. Additionally, FOs facilitate the marketing of farm produce through their bargaining role, enabling farmers to access lucrative markets. This has a direct impact on farmers' revenues, which can be reinvested in adaptation measures [71]. Jung (2017) [72] showed that local organizations enhance actors' capacity to recover from catastrophic events through providing access to critical resources, information, and joint response planning.

The case of Kenyan potato farming highlights the importance of FOs for farm resilience. We observe that farmers are members of FOs mainly to access inputs and services which may help them adapt 
to climate change. In addition, FOs facilitate farmers to obtain access to resources and services from private businesses, non-governmental organizations (NGOs), and county governments. In Meru, for instance, we observed that small village-level farmer groups merged to form a potato cooperative, which provides member farmers with access to credit and certified potato seed in varieties demanded by specific buyers. Farmers are also able to insure their crops, to access extension and training through the cooperative field extension officers, and to enter into a contract farming arrangement. These resources and services have the potential to help farmers to invest in climate adaptation strategies thereby building farm resilience. Based on this literature and corroborated by the illustrative example, we develop the following proposition:

$\mathbf{P}_{2}$. Membership in and access to services provided by FOs improve farmers' adaptive capacity, which, in turn, strengthens farm resilience.

\section{The Nature of Farmer-Buyer Relationships}

In a rapidly changing environment, creative and flexible means to counter the changes are being sought. Some response mechanisms have been through leveraging on trading relations [73], such as transaction relationships between farmers and their buyers [36,74]. These relationships between farmers and their buyers are, by nature, self-organizing, and they continuously evolve to adapt to opportunities and challenges [75]. Emerging farmer-buyer relationships are determined by the nature of the product, the market requirements, the market channel characteristics, and the external environment in which the farm operates [76].

In general, buyers and sellers have the opportunity and freedom to switch their trading partners. However, for some products and given the market conditions facing businesses, a switch is not always an option. For instance, buyers whose business competitive edge depends on a specific crop (i.e., potatoes) have no choice but to nurture the relationship with the crop farmers by supporting them, including helping them in their adaptation strategies. Without good relationships with buyers, farmers may decide to switch to other crops. Strong farmer-buyer relationships help to overcome coordination dilemmas by enhancing the ability to align expectations for mutual benefits [77]. For instance, with strong farmer-buyer relationships, buyers may provide farmers with inputs and credit in a check-off system, allowing them to implement climate adaptation strategies that ultimately benefit both farmers and buyers.

In the past, farmer-buyer relationships were studied in light of improving farm performance [78] or adjusting farm production to changing market and policy environments [79]. These studies showed that farmer-buyer relationships facilitate information exchange, joint decision-making, resource and risk sharing, and joint learning, which improves actors' adaptive capacities [80]. As such, attention to farmer-buyer relationships contributes to overcoming the one-sided focus on farm resilience [21]. Farmer-buyer relationships are also taking place within the Kenya potato farming sub-sector. We showed in our example that, in cases where potato farmers enter into contracts with buyers, the contractor provides farmers with advisory services on potato production and inputs such as certified potato seed. This reduces the burden on farmers and encourages further investment in climate adaptation strategies, such as investment in irrigation. Contract farming arrangements, among other forms of farmer-buyer relationships, underscore the role played by farmer-buyer relationships in influencing farmer adaptive capacity for strengthening farm resilience.

Taking this relational view implies that farm resilience will depend on coordinated responses between the farmers and buyers. These coordinated responses, in turn, depend on the strength of the relationship between farmers and buyers [76,81]. The nature of the trading relationship influences the willingness of farmer and buyer to invest in interdependent activities. For farmers, if the relationship with buyers is important for their investment decision, then the questions that arise are as follows: (a) what relational aspects are most important to enhance the farmer adaptive capacity? and (b) what are the mechanisms through which farmer-buyer relationships influence farmer adaptive capacity? 
In an attempt to answer these questions, we propose an adaptation of the commitment-trust theory from relationship marketing [82].

Within the commitment-trust theory, farmer-buyer relationships may be described in terms of four relational constructs: trust, commitment, power dependency, and satisfaction [81,83]. Previous studies showed that trust positively influences commitment, which drives actors to invest in the relationship (exhibited by investment in the interdependent businesses), which in turn can positively influence business resilience [84]. Wu et al. (2012) [85], in applying the commitment-trust framework, found that higher trust levels improve the quality of interaction between trading parties thereby reducing uncertainties and minimizing the likelihood of an actor exiting the trading relationship.

While it was shown that the relational aspects in a farmer-buyer relationship influence business performance, we argue that the relational aspects are equally important in explaining farm resilience. In a farmer-buyer relationship, the relational aspects influence the investment decisions that farmers make and the practices that they perform on their farms in response to climate change. Srinivasan et al. (2011) [86] argued that, faced with uncertainties, robust supply chain relationships play a role in developing firm's capabilities to deploy resources to achieve the desired outcome- - the firm's adaptive capacity. Argued this way, farmer-buyer relationships anchored on trust, relational commitment, power symmetry, and relational satisfaction improve farmers willingness to make investments that improve their adaptive capacity.

In this paper, we present our conceptual thoughts on how the relational aspects in a farmer-buyer relationship influence farmer adaptive capacity and thus farm resilience. We note, however, that farmer-buyer relationships do not exclusively enhance farmer adaptive capacity but are complementary to other factors such as the farmer EO and the membership in FO (see Figure 1).

In a farmer-buyer relationship, trust arises from constant and detailed information exchange, this create benefits for both the farmer and the buyer. It reflects the extent to which a trading partner has the confidence and believe that the counterpart is honest and benevolent [87]. Accordingly, trust was shown to have positive effects on attitudes, perceptions, behaviors, and performance outcomes [88]. Trust between trading partners enables joint responsibility for each other's business success, shared planning, and flexibility with respect to changes [89]. In farmer-buyer relationships, the presence of relational trust facilitates commitment which influences farmers' investment decisions. In this way, trust can be said to safeguard against opportunistic behavior and reduce transaction costs [83]. Based on this we make, the following proposition:

$\mathbf{P}_{3 \mathbf{a}}$. Trust in farmer-buyer relationships influences the relational commitment.

Relational commitment is defined as the extent to which trading partners devote time and resources to the ongoing trade relationship since they consider the relationship to be important [82]. It is a measure of the strength of the business relationship and explains the survival of the relationship in turbulent times [90]. Where relationships are characterized by a high level of commitment, parties are willing to enter transaction-specific investments that support business resilience. In a farmer-buyer relationship, commitment influences whether farmers and buyers invest in their business for the mutual benefits. Therefore, from a farmer's perspective, commitment plays a central role in shaping the farmer adaptive capacity. In Kenya, for instance, Macchiavello and Morjaria (2015) [91] showed that, even with supply uncertainties, flower farmers were willing to continue investing in the flower production as long as they perceived that their buyers were committed to the trading relationship. While we argue that relational commitment in farmer-buyer relationships is important for farmer adaptive capacity, we note that decisions to commit to the relationship is influenced by the opportunity cost of the next best alternative. In our case, we expect that relational commitment in farmer-buyer relationships influences farmer adaptive capacity.

$\mathbf{P}_{\mathbf{3 b}}$. Relational commitment in farmer-buyer relationships influence the farmer adaptive capacity. 
Relational satisfaction is defined as the extent to which trading partners view the trading relationship as fulfilling and gratifying [92]. Where farmers faced with climate change are satisfied with the trading relationship with their buyers, their commitment to the relationship increases and this allows for investment in adaptation strategies. We, therefore, make the following proposition:

$\mathbf{P}_{4}$. Relational commitment in farmer-buyer relationships mediates the link between relational satisfaction and the farmer adaptive capacity.

Lastly, power dependency refers to the ability of a company to influence the intentions and actions of its trading partner [93]. The way in which the powerful partner in a trading relationship chooses to exercise its power will have an impact on the commitment of the other partner. If it is perceived that a partner is using power to achieve mutual benefits, trading partners develop trust, which increases commitment in the trading relationship. This in turn triggers investment in the business. On the other hand, if a partner is perceived to be using power opportunistically for personal gain, conflict will arise as mistrust develops impeding commitment, and this discourages investment, thus inhibiting adaptation to changes facing the business. This dynamic suggest that the following:

$\mathbf{P}_{5}$. Relational commitment in farmer-buyer relationships mediate the link between power dependency and the farmer adaptive capacity.

\section{Discussion and Suggestions for Testing the Proposed Framework}

In this paper, we present a novel conceptual framework for understanding farm resilience to climate change. We build upon the existing literature on entrepreneurship, farmer organizations, and farmer-buyer relationships to explain the pathways through which farm resilience can be strengthened.

Firstly, we reiterate what was established in the literature, that is, climate change continues to pose a major impact on farm businesses. To counter the adverse effects of climate change, there is an urgent need to build farm resilience. Building farm resilience to climate change requires that stakeholders come up with strategies that improve farmer adaptive capacity [94]. We present farmer adaptive capacity as a pathway through which farm resilience is strengthened. We view farmer adaptive capacity as a prerequisite for adaptation to take place and, thus, necessary resilience building [17]. The question that remains unanswered is as follows: How can the farmer adaptive capacity be strengthened or weakened? To answer this question, we take a farmer perspective and ask what do farmers need to adapt to climate change. We find that farmers need to make investment decisions in order to adapt to climate change such as the adoption of climate-smart agricultural practices.

These investment decisions depend on farmer socioeconomic and psychological characteristics [95], and the collaborations both horizontally and vertically that farmers have with other farmers and buyers, respectively. We identify entrepreneurial orientation (as a farmer psychological characteristic), membership in farmer organizations, and the nature of farmer-buyer relationships as determinants that affect farmer adaptive capacity and thereby farm resilience. We apply our conceptual framework to a specific example of potato farming in Kenya to explore how the framework may be used, how the determinants of farm resilience may be interrelated, and to open a debate for further discussion. This framework reveals important considerations that are often ignored in climate change adaptation studies. Achieving farm resilience is clearly a long-term social process rather than a technical challenge.

The proposed conceptual framework can be operationalized and tested empirically in diverse farming contexts. Firstly, the measures of each of the identified determinants of farm resilience need to be adapted to fit the context under study. For the farmer EO, we propose adaptation of the work of Covin and Wales (2012) [96], who acknowledged farmer EO as decision-making proclivity favoring entrepreneurial activities. With regard to membership in farmer organizations, we propose measures that explore the internal governance structure of the FO and the services that the FO provides to its members. Karadzic et al. (2014) [97] showed that adaptive responses are shaped by membership 
in producer organizations, the internal organizational structures, and learning processes. Lastly, we propose adaptation of the work of Batt [98] on measures of farmer-buyer relationship in attempts to explain the investment decisions that farmers make in the face of climate change.

In sum, as studies on farm resilience grow, incorporating not only the role of the farmer, but also the complex interactions taking place at farm level contributes to overcoming the narrow view on farm resilience.

\section{Policy, Managerial, and Theoretical Implications}

Our proposed framework contributes to the supply chain, entrepreneurship, and farmer organization literature by pointing out how they may support farmer adaptive capacity to manage farm resilience. We provide insights into what constitutes farm resilience within a smallholder farming set-up and how it can be strengthened in a developing country context. From the literature review, we firstly suggest that policy and managerial efforts need to be directed to the approaches that influence farmer entrepreneurship-enabling farmers to be innovative, trigger their risk-taking behavior, and enable them to act proactively. We note that that farmer EO represent a cognitive process and therefore may be influenced through training programs. Secondly, FOs need to be supported endogenously by member farmers or exogenously by outside parties such as governments agencies or NGOs. The support enables the FO to deliver the key services necessary to build farmers adaptive capacity. Thirdly and lastly, there is need to advocate for strong farmer-buyer relationships characterized by trust, relational satisfaction, symmetric power dependency, and relational commitment. Strong farmer-buyer relationships trigger investment decisions by both buyers and farmers for mutual benefit even when faced with uncertainties.

These conceptual findings lead to general implications for development practitioners, managers, and policy-makers. For development practitioners, this review points to the need to target their development interventions toward supporting farmer entrepreneurship and FOs, and advocating for building strong farmer-buyers relationships. For policy-makers, this review provides an indication of the policies that can be formulated or reformulated to strengthen farm resilience. For managers, we point to the potential ways of coping with and adapting to climate change.

Author Contributions: D.K.; D.D. and J.B. contributed to the conceptualization, reviewing and editing of this paper; D.K. contributed to the writing and preparation of the draft versions leading to this publication. All authors have read and agreed to the published version of the manuscript.

Funding: This research was funded by the Netherlands Embassy in Kenya through the 3R (Robust, Resilient and Reliable) project.

Conflicts of Interest: The authors declare no conflict of interest.

\section{References}

1. Sultan, B.; Gaetani, M. Agriculture in West Africa in the Twenty-First Century: Climate Change and Impacts Scenarios, and Potential for Adaptation. Front. Plant Sci. 2016, 7, 1262. [CrossRef] [PubMed]

2. Mancini, M.C. Motivations, Drivers, and Barriers to the Development of Sustainable Agri-Food Systems and Consumption Patterns. Sustainability 2019. (special issue call).

3. Kassie, M.; Teklewold, H.; Jaleta, M.; Marenya, P.; Erenstein, O. Understanding the adoption of a portfolio of sustainable intensification practices in eastern and southern Africa. Land Use Policy 2015, 42, 400-411. [CrossRef]

4. Zeweld, W.; Van Huylenbroeck, G.; Tesfay, G.; Speelman, S. Smallholder farmers' behavioural intentions towards sustainable agricultural practices. J. Environ. Manag. 2017, 187, 71-81. [CrossRef] [PubMed]

5. Campbell; Thornton, P.; Zougmoré, R.; van Asten, P.; Lipper, L. Sustainable intensification: What is its role in climate smart agriculture? Curr. Opin. Environ. Sustain. 2014, 8, 39-43. [CrossRef]

6. Walker, B.; Hollin, C.S.; Carpenter, S.R.; Kinzig, A. Resilience, adaptability and transformability in social-ecological systems. Ecol. Soc. 2004, 9, 5. [CrossRef] 
7. Carpenter, S.; Arrow, K.J.; Barrett, S.; Biggs, R.; Brock, W.A.; Crepin, A.S.; Engstrom, G.; Folke, C.; Hughes, T.P.; Kautsky, N.; et al. General Resilience to Cope with Extreme Events. Sustainability 2012, 4 , 3248-3259. [CrossRef]

8. Meuwissen, M.P.M.; Feindt, P.H.; Spiegel, A.; Termeer, C.J.; Mathijs, E.; de Mey, Y.; Finger, R.; Balmann, A.; Wauters, E.; Urquhart, J.; et al. A framework to assess the resilience of farming systems. Agric. Syst. 2019, 176. [CrossRef]

9. Maleksaeidi, H.; Karami, E.; Zamani, G.H.; Rezaei-Moghaddam, K.; Hayati, D.; Masoudi, M. Discovering and characterizing farm households' resilience under water scarcity. Environ. Dev. Sustain. 2016, 18, 499-525. [CrossRef]

10. Carpenter, S.; Walker, B.; Anderies, J.M.; Abel, N. From metaphor to measurement: Resilience of what to what? Ecosystems 2001, 4, 765-781. [CrossRef]

11. Gitz, V.; Meybeck, A. Risks, vulnerabilities and resilience in a context of climate change. In Building Resilience for Adaptation to Climate Change in the Agriculture Sector; FAO: Rome, Italy, 2012; Volume 23, p. 19.

12. Freduah, G.; Fidelman, P.; Smith, T.F. A framework for assessing adaptive capacity to multiple climatic and non-climatic stressors in small-scale fisheries. Environ. Sci. Policy 2019, 101, 87-93. [CrossRef]

13. Joseph, J. Varieties of Resilience: Studies in Governmentality; Cambridge University Press: Cambridge, UK, 2018.

14. McCarthy, N.; Lipper, L.; Zilberman, D. Economics of Climate Smart Agriculture: An Overview. In Climate Smart Agriculture; Springer, Cham: Berlin/Heidelberg, Germany, 2018; pp. 31-47.

15. Marshall, N.; Park, S.; Howden, S.M.; Dowd, A.B.; Jakku, E.S. Climate change awareness is associated with enhanced adaptive capacity. Agric. Syst. 2013, 117, 30-34. [CrossRef]

16. Smit, B.; Wandel, J. Adaptation, adaptive capacity and vulnerability. Glob. Environ. Chang. Hum. Policy Dimens. 2006, 16, 282-292. [CrossRef]

17. Fazey, I.; Fazey, J.A.; Fischer, J.; Sherren, K.; Warren, J.; Noss, R.F.; Dovers, S.R. Adaptive capacity and learning to learn as leverage for social-ecological resilience. Front. Ecol. Environ. 2007, 5, 375-380. [CrossRef]

18. Brown, K.; Westaway, E. Agency, Capacity, and Resilience to Environmental Change: Lessons from Human Development, Well-Being, and Disasters. Annu. Rev. Environ. Resour. 2011, 36, 321-342. [CrossRef]

19. Yohe, G.; Tol, R.S.J. Indicators for social and economic coping capacity-Moving toward a working definition of adaptive capacity. Glob. Environ. Chang. 2002, 12, 25-40. [CrossRef]

20. Gupta, J.; Termeer, C.; Klostermann, J.; Meijerink, S.; van den Brink, M.; Jong, P.; Nooteboom, S.; Bergsma, E. The Adaptive Capacity Wheel: A method to assess the inherent characteristics of institutions to enable the adaptive capacity of society. Environ. Sci. Policy 2010, 13, 459-471. [CrossRef]

21. Darnhofer, I.; Lamine, C.; Strauss, A.; Navarrete, M. The resilience of family farms: Towards a relational approach. J. Rural Stud. 2016, 44, 111-122. [CrossRef]

22. Jacobi, J.; Schneider, M.; Mariscal, M.P.; Huber, S.; Weidmann, S.; Bottazzi, P.; Rist, S. Farm Resilience in Organic and Nonorganic Cocoa Farming Systems in Alto Beni, Bolivia. Agroecol. Sustain. Food Syst. 2015, 39, 798-823. [CrossRef]

23. Behzadi, G.; O'Sullivan, M.J.; Olsen, T.L.; Scrimgeour, F.; Zhang, A. Robust and resilient strategies for managing supply disruptions in an agribusiness supply chain. Int. J. Prod. Econ. 2017, 191, 207-220. [CrossRef]

24. Falkowski, J. Resilience of farmer-processor relationships to adverse shocks: The case of dairy sector in Poland. Br. Food J. 2015, 117, 2465-2483. [CrossRef]

25. Adomako, S.; Narteh, B.; Danquah, J.K.; Analoui, F. Entrepreneurial orientation in dynamic environments. Int. J. Entrep. Behav. Res. 2016, 22, 616-642. [CrossRef]

26. Iza, C.L.B.; Dentoni, D.; Mordini, M.; Isubikalu, P.; Oduol, J.B.A.; Omta, O. The Role of Farmers' Entrepreneurial Orientation on Agricultural Innovations in Ugandan Multi-Stakeholder Platform. In The Climate-Smart Agriculture Papers; Springer: Berlin/Heidelberg, Germany, 2019; pp. 201-213.

27. Vlasov, M.; Bonnedahl, K.J.; Vincze, Z. Entrepreneurship for resilience: Embeddedness in place and in trans-local grassroots networks. J. Enterprising Communities People Places Glob. Econ. 2018, 12, 374-394. [CrossRef]

28. Doughty, C.A. Building climate change resilience through local cooperation: A Peruvian Andes case study. Reg. Environ. Chang. 2015, 16, 2187-2197. [CrossRef]

29. Gooch, M.; Warburton, J. Building and Managing Resilience in Community-Based NRM Groups: An Australian Case Study. Soc. Nat. Resour. 2009, 22, 158-171. [CrossRef] 
30. Ratner, B.D.; Mam, K.; Halpern, G. Collaborating for resilience: Conflict, collective action, and transformation on Cambodia's Tonle Sap Lake. Ecol. Soc. 2014, 19, 31. [CrossRef]

31. Grothmann, T.; Patt, A. Adaptive capacity and human cognition: The process of individual adaptation to climate change. Glob. Environ. Chang. 2005, 15, 199-213. [CrossRef]

32. Nguyen, T.P.L.; Seddaiu, G.; Virdis, S.G.P.; Tidore, C.; Pasqui, M.; Roggero, P.P. Perceiving to learn or learning to perceive? Understanding farmers' perceptions and adaptation to climate uncertainties. Agric. Syst. 2016, 143, 205-216. [CrossRef]

33. Amankwah-Amoah, J.; Danso, A.; Adomako, S. Entrepreneurial orientation, environmental sustainability and new venture performance: Does stakeholder integration matter? Bus. Strategy Environ. 2019, 28, $79-87$. [CrossRef]

34. Lumpkin, G.T.; Dess, G.G. Clarifying the Entrepreneurial Orientation Construct and Linking It to Performance. Acad. Manag. Rev. 1996, 21, 135-172. [CrossRef]

35. Frank, J.; Penrose-Buckley, C. Small-Scale Farmers and Climate Change: How Can Farmer Organisations and Fairtrade Build the Adaptive Capacity of Smallholders? International Institute for Environment and Development: London, UK, 2012.

36. Kuhl, L. Potential contributions of market-systems development initiatives for building climate resilience. World Dev. 2018, 108, 131-144. [CrossRef]

37. Pelling, M.; High, C.; Dearing, J.; Smith, D. Shadow Spaces for Social Learning: A Relational Understanding of Adaptive Capacity to Climate Change within Organisations. Environ. Plan. A 2008, 40, 867-884. [CrossRef]

38. Manyise, T.; Dentoni, D.; Lans, T.; Trienekens, J. Business models for resilient agri-food systems: If so, when and how? An organizational entrepreneurship perspective. Ecosyst. Serv. 2019. (under review).

39. Vroegindewey, R.; Hodbod, J. Resilience of Agricultural Value Chains in Developing Country Contexts: A Framework and Assessment Approach. Sustainability 2018, 10, 916. [CrossRef]

40. Ministry of Agriculture, Livestock and Fisheries. Kenya Climate Smart Agriculture Implementation Framework 2018-2027. Fisheries and Irrigation, Kenya. Available online: https://www.ke.undp.org/content/dam/kenya/docs/energy_and_environment/2018/The\%20Kenya\% 20CSA\%20Implementation\%20Framework\%202018-2027.pdf (accessed on 15 January 2010).

41. Bernier, Q.; Meinzen-Dick, R.S.; Kristjanson, P.M.; Haglund, E.; Kovarik, C.; Bryan, E.; Silvestri, S. Gender and institutional aspects of climate-smart agricultural practices: Evidence from Kenya. In Working Paper No. 79; CGIAR Research Program on Climate Change Copenhagen: Frederiksberg, Denmark, 2015.

42. World-Bank; CIAT. Climate-Smart Agriculture in Kenya. In CSA Country Profiles for Africa, Asia, and Latin America and the Caribbean Series; The World Bank Group: Washington, DC, USA, 2015.

43. Hyland, J.J.; Heanue, K.; McKillop, J.; Micha, E. Factors influencing dairy farmers' adoption of best management grazing practices. Land Use Policy 2018, 78, 562-571. [CrossRef]

44. Okello, J.; Zhou, Y.; Barker, I.; Schulte-Geldermann, E. Motivations and Mental Models Associated with Smallholder Farmers' Adoption of Improved Agricultural Technology: Evidence from Use of Quality Seed Potato in Kenya. Eur. J. Dev. Res. 2018. [CrossRef]

45. Ansah, I.G.K.; Gardebroek, C.; Ihle, R. Resilience and household food security: A review of concepts, methodological approaches and empirical evidence. Food Secur. 2019. [CrossRef]

46. Bijman, J. Contract Farming in Developing Countries: An Overview; Wageningen University, Department of Business Administration: Wageningen, The Netherlands, 2008.

47. Gunderson, L.H. Ecological resilience-In theory and application. Annu. Rev. Ecol. Syst. 2000, 31, $425-439$. [CrossRef]

48. Walker, B.; Carpenter, S.; Anderies, J.; Abel, N.; Cumming, G.; Janssen, M.; Lebel, L.; Norberg, J.; Peterson, G.; Pritchard, R. Resilience management in social-ecological systems: A working hypothesis for a participatory approach. Conserv. Ecol. 2002, 6, 14. [CrossRef]

49. Engle, N.L. Adaptive capacity and its assessment. Glob. Environ. Chang. 2011, 21, 647-656. [CrossRef]

50. Cinner, J.; Adger, W.N.; Allison, E.H.; Barnes, M.L.; Brown, K.; Cohen, P.J.; Gelcich, S.; Hicks, C.C.; Hughes, T.P.; Lau, J.; et al. Building adaptive capacity to climate change in tropical coastal communities. Nat. Clim. Chang. 2018, 8, 117-123. [CrossRef]

51. Armitage, D. Building resilient livelihoods through adaptive co-management: The role of adaptive capacity. In Adaptive Co-Management: Collab. Learn. Multi-Level Gov.; Armitage, D., Berkes, F., Doubleday, N.C., Eds.; UBCPress: Toronto, ON, Canada, 2007; pp. 62-82. 
52. Angeler, D.G.; Fried-Petersen, H.B.; Allen, C.R.; Garmestani, A.; Twidwell, D.; Chuang, W.-C.; Donovan, V.M.; Eason, T.; Roberts, C.P.; Sundstrom, S.M.; et al. Adaptive capacity in ecosystems. In Resilience in Complex Socio-Ecological Systems; Elsevier Ltd.: London, UK, 2019; pp. 1-24.

53. Dentoni, D.; Pinkse, J.; Lubberink, R. A complex adaptive system view on business model partnerships for sustainability. In Proceedings of the 6th Cross-Sector Social Interactions Conference, Copenhagen, Denmark, 10 June 2018.

54. Douglass-Gallagher, E.; Stuart, D. Crop Growers' Adaptive Capacity to Climate Change: A Situated Study of Agriculture in Arizona's Verde Valley. Environ. Manag. 2019, 63, 94-109. [CrossRef] [PubMed]

55. Milestad, R.; Westberg, L.; Geber, U.; Bjorklund, J. Enhancing Adaptive Capacity in Food Systems: Learning at Farmers' Markets in Sweden. Ecol. Soc. 2010, 15, 29. [CrossRef]

56. McInnis-Bowers, C.; Parris, D.L.; Galperin, B.L. Which came first, the chicken or the egg? Exploring the relationship between entrepreneurship and resilience among the Boruca Indians of Costa Rica. J. Enterprising Communities People Places Glob. Econ. 2017, 11, 39-60. [CrossRef]

57. Darnhofer, I.; Bellon, S.; Dedieu, B.; Milestad, R. Adaptiveness to enhance the sustainability of farming systems. A review. Agron. Sustain. Dev. 2010, 30, 545-555. [CrossRef]

58. Frank; Eakin, H.; López-Carr, D. Social identity, perception and motivation in adaptation to climate risk in the coffee sector of Chiapas, Mexico. Glob. Environ. Chang. 2011, 21, 66-76. [CrossRef]

59. Tucker, C.M.; Eakin, H.; Castellanos, E.J. Perceptions of risk and adaptation: Coffee producers, market shocks, and extreme weather in Central America and Mexico. Glob. Environ. Chang. Hum. Policy Dimens. 2010, 20, 23-32. [CrossRef]

60. Groot, J.C.J.; Cortez-Arriola, J.; Rossing, W.A.H.; Massiotti, R.D.A.; Tittonell, P. Capturing Agroecosystem Vulnerability and Resilience. Sustainability 2016, 8, 1206. [CrossRef]

61. Meinzen-Dick, R.; DiGregorio, M.; McCarthy, N. Methods for studying collective action in rural development. Agric. Syst. 2004, 82, 197-214. [CrossRef]

62. Bijman, J.; Muradian, R.; Schuurman, J. Cooperatives, Economic Democratization and Rural Development; Edward Elgar Publishing: Cheltenham, UK, 2016.

63. Boyd, E.; Osbahr, H.; Ericksen, P.J.; Tompkins, E.; Lemos, M.C.; Miller, F. Resilience and 'Climatizing' Development: Examples and policy implications. Development 2008, 51, 390-396. [CrossRef]

64. Tompkins, E. Planning for climate change in small islands: Insights from national hurricane preparedness in the Cayman Islands. Glob. Environ. Chang. 2005, 15, 139-149. [CrossRef]

65. Kearney, J.; Berkes, F. Communities of Interdependence for Adaptive Co-Management; UBC Press: Vancouver, BC, Canada, 2007.

66. Jacobi, J.; Schneider, M.; Bottazzi, P.; Pillco, M.; Calizaya, P.; Rist, S. Agroecosystem resilience and farmers' perceptions of climate change impacts on cocoa farms in Alto Beni, Bolivia. Renew. Agric. Food Syst. 2013, 30, 170-183. [CrossRef]

67. Borda-Rodriguez, A.; Vicari, S. Coffee Co-Operatives in Malawi: Building Resilience through Innovation. Ann. Public Coop. Econ. 2015, 86, 317-338. [CrossRef]

68. Bentley, J.W. Folk experiments. Agric. Hum. Values 2006, 23, 451-462. [CrossRef]

69. Kummer, S.; Milestad, R.; Leitgeb, F.; Vogl, C.R. Building Resilience through Farmers' Experiments in Organic Agriculture: Examples from Eastern Austria. Sustain. Agric. Res. 2012, 1, 308-321. [CrossRef]

70. Pelletier, B.; Hickey, G.M.; Bothi, K.L.; Mude, A. Linking rural livelihood resilience and food security: An international challenge. Food Secur. 2016, 8, 469-476. [CrossRef]

71. Borsky, S.; Spata, M. The Impact of Fair Trade on Smallholders' Capacity to Adapt to Climate Change. Sustain. Dev. 2018, 26, 379-398. [CrossRef]

72. Jung, K. Sources of Organizational Resilience for Sustainable Communities: An Institutional Collective Action Perspective. Sustainability 2017, 9, 1141. [CrossRef]

73. Fischer; Reynolds, N. Collaborative advantage, relational risks and sustainable relationships: A literature review and definition. In Agri-Food Chain Relationships; CABI: Wallingford, UK, 2010; pp. 74-89.

74. Irwin, B.; Campbell, R. Market Systems for Resilience; USAID, Leveraging Economic Opportunity (LEO) Project; United States Agency for International Development (USAID): Washington, DC, USA, 2015.

75. Campbell. A Framework for Inclusive Market Systems Development. USAID. Available online: http://acdivoca.org/sites/default/files/attach/legacy/site/Lookup/LEO-Market-Systems-Framework/\$file/ LEO-Market-Systems-Framework.Pdf (accessed on 14 September 2019). 
76. Dlamini-Mazibuko, B.P.; Ferrer, S.; Ortmann, G. Examining the farmer-buyer relationships in vegetable marketing channels in Eswatini. Agrekon 2019, 58, 369-386. [CrossRef]

77. Mesquita, L.F.; Lazzarini, S.G. Horizontal and vertical relationships in developing economies: Implications for SMEs' access to global markets. Acad. Manag. J. 2008, 51, 359-380. [CrossRef]

78. Xhoxhi, O.; Pedersen, S.M.; Lind, K.M. How does the intermediaries' power affect farmers-intermediaries' trading relationship performance? World Dev. Perspect. 2018, 10-12, 44-50. [CrossRef]

79. Zhang, X.Y.; Hu, D.H. Farmer-buyer relationships in China: The effects of contracts, trust and market environment. China Agric. Econ. Rev. 2011, 3, 42-53. [CrossRef]

80. Scholten, K.; Schilder, S. The role of collaboration in supply chain resilience. Supply Chain Manag. Int. J. 2015, 20, 471-484. [CrossRef]

81. Chen, Z.; Huang, Y.; Sternquist, B. Guanxi practice and Chinese buyer-supplier relationships: The buyer's perspective. Ind. Mark. Manag. 2011, 40,569-580. [CrossRef]

82. Morgan, R.M.; Hunt, S.D. The commitment-trust theory of relationship marketing. J. Mark. 1994, 58, $20-38$. [CrossRef]

83. Batt, P.J. Building trust between growers and market agents. Supply Chain Manag. Int. J. 2003, 8, 65-78. [CrossRef]

84. Mandal, S.; Sarathy, R. The Effect of Supply Chain Relationships on Resilience: Empirical Evidence from India. Glob. Bus. Rev. 2018, 19, S196-S217. [CrossRef]

85. Wu, M.Y.; Weng, Y.C.; Huang, I.C. A study of supply chain partnerships based on the commitment-trust theory. Asia Pac. J. Mark. Logist. 2012, 24, 690-707. [CrossRef]

86. Srinivasan, M.; Mukherjee, D.; Gaur, A.S. Buyer-supplier partnership quality and supply chain performance: Moderating role of risks, and environmental uncertainty. Eur. Manag. J. 2011, 29, 260-271. [CrossRef]

87. Anderson, J.C.; Narus, J.A. A model of distributor firm and manufacturer firm working partnerships. J. Mark. 1990, 54, 42-58. [CrossRef]

88. Dirks, K.T.; Ferrin, D.L. The Role of Trust in Organizational Settings. Organ. Sci. 2001, 12, 450-467. [CrossRef]

89. Johnston, D.A.; McCutcheon, D.M.; Stuart, F.I.; Kerwood, H. Effects of supplier trust on performance of cooperative supplier relationships. J. Oper. Manag. 2004, 22, 23-38. [CrossRef]

90. Masuku, M.B.; Kirsten, J.F.; Van Rooyen, C.J.; Perret, S. Contractual Relationships between Small-Holder Sugarcane Growers and Millers in the Sugar Industry Supply Chain in Swaziland. Agrekon 2003, 42, 183-199. [CrossRef]

91. Macchiavello, R.; Morjaria, A. The Value of Relationships: Evidence from a Supply Shock to Kenyan Rose Exports. Am. Econ. Rev. 2015, 105, 2911-2945. [CrossRef]

92. Geyskens, I.; Steenkamp, J.-B.E. Economic and social satisfaction: Measurement and relevance to marketing channel relationships. J. Retail. 2000, 76, 11-32. [CrossRef]

93. Benton, W.C.; Maloni, M. The influence of power driven buyer/seller relationships on supply chain satisfaction. J. Oper. Manag. 2005, 23, 1-22. [CrossRef]

94. Mashizha, T.M. Building adaptive capacity: Reducing the climate vulnerability of smallholder farmers in Zimbabwe. Bus. Strategy Dev. 2019, 2, 166-172. [CrossRef]

95. Eakin, H.; York, A.; Aggarwal, R.; Waters, S.; Welch, J.; Rubiños, C.; Smith-Heisters, S.; Bausch, C.; Anderies, J.M. Cognitive and institutional influences on farmers' adaptive capacity: Insights into barriers and opportunities for transformative change in central Arizona. Reg. Environ. Chang. 2016, 16, 801-814. [CrossRef]

96. Covin, J.G.; Wales, W.J. The Measurement of Entrepreneurial Orientation. Entrep. Theory Pract. 2012, 36, 677-702. [CrossRef]

97. Karadzic, V.; Antunes, P.; Grin, J. Adapting to environmental and market change: Insights from Fish Producer Organizations in Portugal. Ocean Coast. Manag. 2014, 102, 364-374. [CrossRef]

98. Batt, P.J. Examining the performance of the supply chain for potatoes in the Red River Delta using a pluralistic approach. Supply Chain Manag. Int. J. 2003, 8, 442-454. [CrossRef]

(C) 2020 by the authors. Licensee MDPI, Basel, Switzerland. This article is an open access article distributed under the terms and conditions of the Creative Commons Attribution (CC BY) license (http://creativecommons.org/licenses/by/4.0/). 